pheric levels. That trend will suit the crisis mongerers just fine, except none of it will help anyone understand their own situation or where international comparisons truly matter. And for non-OECD countries where census methodologies and coverage have not fully matured, population ratio comparisons are even more problematic.

And that is the more important point. The numbers do not help us do what we have to do. They steer us away from the task of refashioning the pieces of paper we award into meaningful documents, representing learning that helps our students compete in a world without borders. Instead of obsession with ratios, we should look instead to the action lines of the Bologna process: degree qualification frameworks, a "tuning" methodology that creates reference points for learning outcomes in the disciplines, the discipline-based benchmarking statements that tell students precisely what to expect of their educational journey and the public precisely what learning our institutions should be accountable for, Diplomas Supplements that warrantee student attainment, more flexible routes of access, and ways of identifying and targeting for participation underrepresented populations through geocoding. Slowly but surely, these features of Bologna are shaping a new global paradigm for higher education, and in that respect other countries are truly doing better. We should all be studying the substance, perhaps experiencing an epiphany or two about how to turn the big ship or the small skiffs on which we travel into the currents of global reform.

\section{The Reinvention of}

\section{Undergraduate Education in Hong Kong}

\section{Martin J. Fin Kelstein ANd Elaine M. Walker}

Martin J. Finkelstein is professor of higher education at Seton Hall University, South Orange, NJ, USA. He was a Fulbright Senior Specialist in Hong Kong. E-mail: finkelma@shu.edu. Elaine M. Walker is a visiting scholar at Seton Hall University and the University of Hong Kong.

$I^{2}$

n 2004/05, the government of Hong Kong authorized a 1 major reform of its eight public universities-known as the "3-3-4 reforms." To be implemented in 20I2, the three-year undergraduate degree program, focused exclusively on a profession or academic field, will be changed to a four-year undergraduate degree program, including a substantial component of nonspecialized or general education. While many factors contributed to the government's action, two overriding factors were a desire to ensure the future competitiveness of Hong
Kong in the global knowledge economy and to align Hong Kong's educational pipeline with those in the Chinese mainland, the United States, and the European Union.

On the face of it, Hong Kong's 3-3-4 reforms represent another classic case of government imposing far-reaching changes on universities. Two factors, however, distinguish the Hong Kong "experiment" from typical government intervention: first, the mandates encourage distinctiveness in the response of individual institutions according to their missions and history; and second, the universities have received considerable lead time and a modest infusion of additional resources from the government.

To be implemented in 2012, the three-year undergraduate degree program, focused exclusively on a profession or academic field, will be changed to a four-year undergraduate degree program

The eight public universities funded through the University Grants Committee include three historically research-intensive universities (the English-language University of Hong Kong, the bilingual Chinese University of Hong Kong, and the University of Science and Technology); two former polytechnics (Polytechnic University and City University); the Hong Kong Baptist University (founded by American Baptists in the I950s and incorporated into the University Grants Committee public system in 1987); Lingnan University (with a focus on undergraduate liberal arts); and the Hong Kong Institute for Education (with a specialized teacher training and master's level focus).

\section{Current DeVelopments}

Nearly all the universities have established faculty and administrative task forces within the formal academic governance structure to drive the institutional planning process; and several have established new administrative positions to direct the process. Providing reports to the University Grants Committee is required biennially. While all institutions have focused their efforts on designing a first-year transitional undergraduate experience, most are concentrating as well on a redesign of the major, to promote specific learning objectives-including renewed emphasis on outside the classroom experiences (e.g., internships and service learning off campus) and foreignexchange study opportunities on the mainland and across Asia and the world.

\section{Academic Staffing Challenges}

Such broad-based curricular redevelopment poses several major challenges: Who will do the curricular development and delivery? What incentives will entice the "best" faculty to 
become engaged in these new initiatives at the expense of their research and publication activity? Research intensive institutions will have to create approaches to bring the faculty into this reinvention in a way not viewed as threatening to their long-term career interests. If this approach fails on a sufficiently large scale with the regular research faculty, will new kinds of academic staff need to be recruited to undertake this special general education work?

\section{Such broad-based curricular redevelopment poses} several major challenges: Who will do the curricular development and delivery? What incentives will entice the "best" faculty to become engaged in these new initiatives at the expense of their research and publication activity?

All of these new educational opportunities are very labor intensive for institutions to mount effectively, on a small as well as large scale. Who will carry out work? Current faculty? A new breed of academic staff? At what cost and with what benefit in the long term? Ultimately, Hong Kong's universities, and especially its research institutions, must balance attention on this innovation of their educational role, with the need to produce relevant research to advance their place in the global knowledge economy.

\section{Assessment Challenge}

Finally, there is the assessment challenge. The reforms mandated appropriate assessment methods to demonstrate that educational goals are being achieved. How will institutions determine whether the panoply of new courses, internship opportunities, and foreign study is actually achieving the intended outcomes? This question must be answered at multiple levels ranging from the individual academic program, to the faculty, to the institution, and ultimately to the entire higher education sector. These assessments will be vital both as a basis for improvement (or quality assurance) and for determining the costs and benefits of the new educational order. By comparison, the assessment of the research mission has already come a long way.

\section{New Opportunities?}

A number of universities, especially the three focused on research, are using the 3-3-4 reforms as an opportunity to grow-augmenting their academic staffs by io to 20 percent and expanding professional staff in the student service area. This hiring expansion provides a stunning (once in a lifetime) opportunity to recast and reform the academic staff in service of a new order.

Over the coming decade, Hong Kong will be a system to watch - a virtual laboratory for the examination of change in higher education that conjoins government mandates with enlightened government support.

\section{New Publications}

Ackers, Louise, and Byrony Gill. Moving People and Knowledge: Scientific Mobility in an Enlarging European Union. Northampton, MA: Edward Elgar Publishing, 2009. 288 pp. \$I25 (hb). ISBN 978-I-84376-985-9. Web site: www.e-elgar.com.

An analysis of patterns of migration of highskill people in the European Union, this volume discusses the circulation of talent, including patterns of return. It also looks at networks, the migration process, the impact on children and families, and the experiences of receiving and sending countries.

Angulo, A. J. William Barton Rogers and the Idea of MIT. Baltimore: Johns Hopkins University Press, 2009. 220 pp. $\$ 55$ (hb). ISBN 978-0-8018-9033-8. Web site: www.press.jhu.edu.

The Massachusetts Institute of Technology is a special and unusual university. Its roots are in the development of technical higher education in the United States in the midIgth century. Rogers, the founder of MIT and its leading thinker, is a unique figure in the history of American higher education. This volume combines a biography of Rogers with a history of the ideas and developments behind the early years of MIT.

Bastiaens, Jo. International Assistance and State-University Relations. New York: Routledge, 2009. 239 pp. \$95 (hb). ISBN 978-0-4I5-99074-5. Web site: www.routledge.com.

A detailed study of international donor assistance for Indonesian higher education, this book discusses how government agencies and international donors interrelated in the process of assistance programs. Dutch programs in Indonesia are the main focus of the study. The results, while relating to
Indonesia, have relevance to donor-government relations internationally.

Byram, Mike, and Fred Dervin, eds. Students, Staff and Academic Mobility in Higher Education. Newcastle, UK: Cambridge Scholars Publishing, 2008. 3I3 pp. (hb). ISBN 978-I-847i 86034 . Web site: www.c-s-p.org.

A multifaceted discussion of student mobility worldwide, this volume features chapters focusing on a variety of European countries and Israel. Several comparative analyses are included, as are a few chapters focusing on faculty mobility.

Ehrenberg, Ronald G., and Charlotte V. Kuh, eds. Doctoral Education and the Faculty of the Future. Ithaca, NY: Cornell University Press, 2009. 320 pp. \$35 (hb). ISBN 978-0-80I44543-9 Web site: www.cornellpress.cornell .edu.

The concern of the authors of this book is 